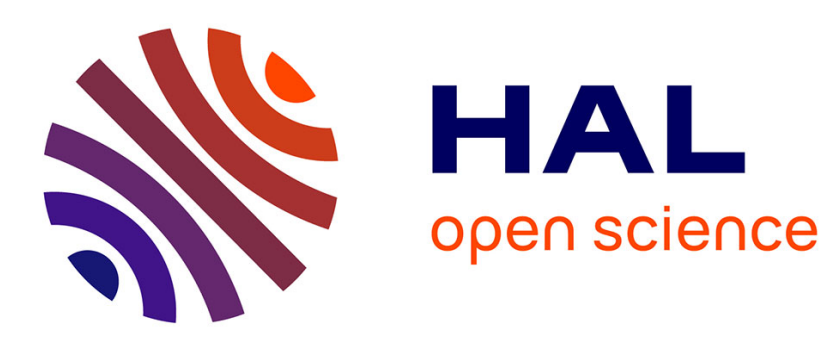

\title{
Transnational Trade and New Types of Entrepreneurs in Algeria
}

Saïd Belguidoum

\section{To cite this version:}

Saïd Belguidoum. Transnational Trade and New Types of Entrepreneurs in Algeria. Yahia H. Zoubir. The politics of Algeria: Domestic Issues and International Relations, Taylor \& Francis, 2019, 9781138331006. 10.4324/9780429447495-16 . halshs-02401267

\section{HAL Id: halshs-02401267 https://shs.hal.science/halshs-02401267}

Submitted on 8 Sep 2022

HAL is a multi-disciplinary open access archive for the deposit and dissemination of scientific research documents, whether they are published or not. The documents may come from teaching and research institutions in France or abroad, or from public or private research centers.
L'archive ouverte pluridisciplinaire HAL, est destinée au dépôt et à la diffusion de documents scientifiques de niveau recherche, publiés ou non, émanant des établissements d'enseignement et de recherche français ou étrangers, des laboratoires publics ou privés. 


\title{
Transnational Trade and New Types of Entrepreneurs in Algeria
}

\author{
Saïd Belguidoum
}

Aix Marseille Université, CNRS, IREMAM, Aix-en-Provence, France

\begin{abstract}
Algeria is emblematic of reorganised commercial supply networks in the southern Mediterranean. The boom in imported consumer products labelled "Made in China" has led to a reorganisation of Algerian supply networks and the places in which those goods are sold. In three decades, there has been a shift from "globalization from below" (Portes, 1999), limited to a few regions of the world and driven by pioneering migrant entrepreneurs, to a true globalisation of the entire trade structure. This transnational commerce has freed itself from the heritage of postcolonial domination which had previously dominated trade between the global north and south.
\end{abstract}

Within this global trade framework, supply routes have multiplied. Commercial hubs have sprung up on all continents where transnational entrepreneurs from countries all over the world meet; the business trip to Dubai, Istanbul or China has become commonplace. At the heart of these new dynamics, new traders have adopted the system of trading posts on transnational routes that they helped to create. In thirty years, three generations and three different kinds of traders have succeeded one another.

This emergence of international routes, and the rapidity and very large scale in which they arose, raise questions about these new entrepreneurs. Breaking with traditional supply circuits, their initiative is remarkable, even more so since these economic actors are often young. While some of them do come from trading families, nothing destined them to become the pioneers of these new routes.

What is equally remarkable is how such a change could have occurred in a country where the private sector has long been marginalised and in which private business still has an ambiguous and controversial identity in an economy caught between the rigours of strict bureaucracy and unrestrained distribution markets.

This article focuses on the specific actors in this transnational economy and on 'globalization from below'. It draws on field research in several sites (Algeria, Dubai, China) and attempts to show how these new kinds of entrepreneurs have come into being in a country that is still in the making.

From Managed Economy to Liberalisation: Slow Steps toward Private Enterprise in Algeria

The emergence of a private sector in Algeria must be understood within the general context of this country and the dominant role played by the state in all sectors of society since independence. In the years following independence, a managed economy was chosen for 
development, whereby the pervasive state was both regulator and main operator of the economy. Through its active and interventionist policies, its regulations, and its bureaucracy, the state played a leading role in stimulating and controlling the major transformations that Algerian society has undergone. As for private enterprise, it has long been confined to the margins of public policy (Addi, 1990).

To understand this situation, it is necessary to mention the neo-patrimonial nature of the state. Neopatrimonialism (Eisenstadt, 1973; Médard, 1991) results from a combination of a bureaucratic system, which manifests through the institutions that conform with a modern state, and practices of clientelism and allegiance to power that enable one to obtain special privileges, particularly access to economic resources. Such a system maintains permanent confusion between the public and private domains and is based on the permeability of the borders between politics and economics. As a result of this confusion there is constant suspicion towards the private sector, which has to operate within the clientelism, corruption, and informality generated by this type of governance.

The Boumediene years (1965-1979) saw the triumph of populist ideology inherited from the national liberation movement, which considered that development was the responsibility of the state as conductor and manager of the economy. During this period the foundations of the neo-patrimonial State were established, based on the redistribution policy made possible by high oil revenues. From 1996 onwards a period of economic liberalisation began, although the shackles of the administered economy remained. The State transferred its monopoly prerogatives to private groups, assigning them import markets for a number of commodities such as basic food staples (oil, sugar, coffee), pharmaceuticals, construction materials and industrial equipment (Hachemaoui, 2012).

As this bureaucratic and clientelist system was pushed to its limits, the neo-patrimonial State organised and distributed privileges within the economy while allowing entire sections of informality to flourish. Thus, we have the paradox of a society whose economy oscillated between an unbridled laissez-faire attitude in many sectors of economic and social life (particularly wholesale distribution and retail) and an omnipresent bureaucracy.

Since the economic opening of the 1990s, some major private figures have emerged. Large corporations have acquired public recognition: Mehri, Rebrab (CEVITAL), Condor, Hasnaoui (construction and real estate development), Haddad (ETRHB), and BIOPHARM (pharmaceutical industry) to mention some of the best known. The regular public policy statements by the President of the Entrepreneurs' Forum attest to the desire for legitimacy that entrepreneurs wanted. But the Khelifa affair, a consortium that quickly came to dominate the economy before collapsing after bankruptcy and the arrest of its CEO, continues to weigh heavily on public opinion, which suspects the private sector of corruption and of taking public money.

This is the context in which the Algerian private industry is growing. In full expansion since the economic opening (76\% of these companies were created between 2000 and 2011), 
private business accounts for $98 \%$ of all economic entities and employs $73.2 \%$ of the economically active population (excluding agriculture, administration, and education). ${ }^{i}$ However, for the most part, these are small companies with little capitalisation: $98.7 \%$ of private companies have fewer than 10 employees and only 932 companies, out of the 915316 existing, report having more than 250 employees.

\section{Mass Consumption and the Emergence of Trans-national Entrepreneurs}

In a country that depends largely on the redistribution of gas and oil revenues, the services and trade sector have the most intense business. It is mainly in the tertiary sector that the private sector is growing, with $89 \%$ of business, $55.6 \%$ of which is for trade in its various forms. As the needs of an ever-increasing population are growing, the state, unable to meet this new demand, is liberalising the economy.

Until 1996 foreign trade was closely controlled by the state through its public companies. The amendment of the Commercial Code has radically transformed this framework, enabling 34 000 private import companies to be set up in less than ten years. By abandoning a managed economy, which gave the State a monopoly on imports, and by enacting new rules on imports and the foreign currency market (with its often strict and confusing rules which are regularly changed, favouring informed agents), the State left the field partially open for a free market that new agents could access. A multitude of hybrid practices in both imports and distribution in the domestic market occur alongside this shift, playing on the confusion between licit and illicit practices. The porosities and laxity of an inefficient legal system (lack of coordination between agencies for control, trade registers with fake addresses, generalised tolerance of the parallel currency market, etc.), and the interpenetration between the interests of private companies and those of government officials, encouraged the development of the free enterprise while ensuring the large-scale supplying of the Algerian market.

While the vast majority of entrepreneurs specialise in retail (84\%), a growing number of wholesalers and importers have been organising a market whose products are mainly imported. The growth of these companies has been rapid, from 21500 in 2006 to 34100 in 2010 for import companies and from 41,200 to 66900 for wholesale companies (CNRC, 2011). These new entrepreneurs set up a supply system that flooded the Algerian market with consumer goods. Their rapid rise is generally considered illegitimate and is associated with pariah capitalism (Péraldi, 2007). In fact, this refers to a very distinct category of new economic operators. They have taken over a space that is difficult to monopolise and therefore escapes the system of kickbacks of the 'protected people' in the neo-patrimonial system: the consumer goods market in personal goods (clothing, cosmetics, sports goods, toys, etc.), household goods (furniture, household articles and linens, light fixtures, cleaning products, computing and mobile telephony), and other small objects of everyday life (small commodities). This new dynamic can only be understood by placing it within the general context of globalisation. 


\section{Discreet Globalisation and the Transnational Economy}

Since the end of the 1990s, and in the wake of the globalisation of the capitalist economy, a discreet but effective transnational trade has arisen, bringing to light new kinds of entrepreneurs. This is the result of a double process: first, the growth of a consumer market linked to the emergence of large urban middle and working classes in the countries of the global south that have been neglected by multinational companies; and second, the progressive emancipation of supply chains from their post-colonial framework, allowing for the emergence of new sources of supply of consumer goods supply.

Portes (1999) and Tarrius (2002) were among the first to highlight the specificities of this new form of 'globalization from below,' a term coined by Portes. In his work on Latin American migrants to the USA, he found that the new dynamics of transnationalism were a response to globalisation by migrant 'communities that sit astride political borders... that, in a very real sense, are "neither here nor there" but in both places simultaneously' (Portes, 1999:16). He showed that 'The economic activities that sustain these communities are grounded precisely on the differentials of advantage created by state boundaries. In this respect, they are no different from the large global corporations, except that these enterprises emerge at the grassroots level and its activities are often informal' (ibid.).

Echoing this sentiment Tarrius describes and analyses 'the origins, in the western Mediterranean, of real networks of mobile entrepreneurs...they attest to the fact that another globalization does actually exist: a discreet globalization, from the bottom-up, which is rarely studied and yet has weighty consequences for our future' (Tarrius, 2002:15).

The transnational economy, which was based for a time on immigrant communities, subsequently grew thanks to a new generation of migrants, those travelling entrepreneurs who settled for varying periods in the trading posts of these new places supplying the global economy with consumer goods. These actors have the know-how to 'sit astride political borders' (Portes, 1999) and 'have the ability to be here, there, and here and there at the same time' (Tarrius, 2002).

These discrete, alternative supply spaces were created on the margins of globalisation, enabling networks of transnational traders to play on the advantages created by different practices at different borders (currency exchange, purchasing power, customs taxation).

\section{The Establishment of Transnational Trade Routes}

The process has been rapid and occurred in two main phases: from transport by bags to containers, in other words, the transition from a resourceful amateur working in an essentially cross-border economy (France, Tunisia, Morocco) to that of a transnational economy with professional networks. Two supply and distribution routes were linked. The first one, transnational, is a network of trading posts. Originally located in Marseille, these trading centers then moved to Istanbul and Dubai, before going further back up the road to the source in China: Hong Kong, Guangzhou, Shenzhen and primarily, Yiwu. The second route, a national one, supplanted the 'souk' network that had been used as for distribution. In three 
decades, new roads and trade centers were built connecting urban spaces linked together by flows of traders and goods. These spaces are discontinuous and discrete, networked and constantly shifting. More important than the scale of nation-states, it is the scale of places and regions, their influence, and the roads that connect them that make up the defining characteristics and strength of this transnational economy (Belguidoum \& Pliez, 2015: 2).

Initially, an informal commerce carrying bags of goods, called trabendo, ensured the supply for a booming market. Although this kind of trade has not disappeared, it was quickly replaced by trade using containers (Péraldi, 2001). The visibility of the bag trade probably explains why today the transnational economy continues to be confused with the informal economy. Of course, informality exists in transnational trade. For example, many traders try to hide part of their revenue to avoid taxation, importers make extensive use of the parallel currency market, and goods are ultimately sold through a very informal retail distribution system. But if we content ourselves with the generic term 'informal' to classify a new form of world trade, we are prevented from seeing the nature of this economy. 'Informal' is a blanket term and not very useful to describe practices. With strong pejorative connotations in Algeria, it refers to any business that is not regulated by the state, particularly in terms of taxation. This notion confuses the extreme diversity of statuses and situations and puts in the same basket licit and illicit, legal and illegal activities, smuggling, counterfeiting, under-declaring at customs, sales without officially registering the business, and so on. Using this term as a yardstick, there would thus be no economy except under the conditions set by the State within the limits of its organisational, normative, and financial scope of action.

The strength of this transnational trade is that it has discreetly taken hold on the margins of the global economy by appropriating untapped areas or creating new areas.

\section{The Spaces, Trading Centers, and Routes of this New Trade}

In Algeria, this Silk Road has materialised in the development of a network of commercial towns combining the experience and skills these new traders have acquired in recent decades. Large urban and suburban marketplaces are emerging, reconfiguring the framework and the internal structure of cities through the creation of shopping streets and commercial districts. Small, medium and large cities are affected by these distribution networks that supply the numerous weekly markets, boutiques and stores that proliferate in increasingly specialised urban neighborhoods. There is not a city today, large or small, that does not have its own market for imported consumer goods. At the end of 2010, the Algerian government identified some 765 sites of informal commerce, as many as there are towns, in which some 70000 traders operate. This shows the extent of the phenomenon.

Although peripheral at the beginning, these places have consolidated, specialised, and professionalised as they have grown. At one end of these routes is China, from where manufactured goods leave for the entire planet. At the other end is an ever-growing mass consumer market, reaching people that had previously been left out. These markets are certainly not linked exclusively to Chinese supply chains as Turkey, the Middle East, Dubai, 
Malaysia and recently Indonesia are other sources. There are many emerging regional and local markets (the branches of these new silk routes), numerous trading centers they connect, and actors working in them. This networked economy has the capacity to adapt very quickly to changes in markets and customs regulations.

In Algeria, the network of markets selling imported goods is becoming more hierarchical and specialised as supply routes change. Of the 34000 officially registered importers, $68 \%$ are concentrated in five wilayas: Algiers, Oran, Setif, Constantine, and Oum el Bouaghi (CNRC, 2011).

It is above all in eastern Algeria that these networks of traders have gained visibility by operating in medium-sized and small towns, which have become real trading centers controlling the distribution market. Medium-sized cities (El Eulma, Aïn M'lila), small towns, and large villages (Aïn Fakroun, Tadjenanet, Bir el-Ater) are becoming commercial hubs, organising the distribution of goods imported by their entrepreneurs. Their concentration in eastern Algeria is partly due to their close proximity to the Tunisian and Libyan borders, but they are not necessarily located on the main traffic routes. They have emerged there more because of the special drive of a category of new actors. El Eulma (furniture, mobile telephony, computing, cleaning products and hardware), Aïn M'lila (spare parts for cars) and Aïn Fakroun (clothing) are the three towns that have become dominant over the past ten years in their specific field, extending their distribution network throughout Algeria and even beyond by establishing links with Moroccan, Tunisian and Libyan traders. Other towns in Eastern Algeria have also specialized in less visible goods. This is the case of Belaïba and El Djezar (spare parts for public works machinery and heavy vehicles), small towns located near Barika and Bir el-Ater in the wilaya of Tébessa (second-hand clothing), which was once a hub for products from Libya, and Tadjenanet near El Eulma, very active in importing wood.

\section{El Eulma and Yiwu: Essential Places of Algerian Trade}

We cannot understand how the Algerian route works without taking into account the essential role played by two towns: Yiwu and El Eulma, two discreet and emblematic localities of this kind of globalisation.

\section{Yiwu: The Starting Point for the New Silk Road}

This city of 1.5 to 2 million people, located $280 \mathrm{~km}$ from Shanghai in Zhejiang province, is the largest wholesale market in China and one of the largest in the world, specialising in the sale of small items such as stationery, jewelry, DIY, interior decorations. In the early 2000s, Yiwu became the necessary starting point and location for transnational trade offices for people from countries all over the world. Many Algerian merchants come here to place orders. There are also about fifty registered Algerian freight forwarding offices; many Algerian traders also work unofficially by going through Chinese partners. In 2011, Algeria became the tenth-largest importer of Yiwu products (Belguidoum \& Pliez, 2015:1). 


\section{El Eulma, The Emblem of Transnational Trade in Algeria}

At the same time, El Eulma in Algeria has become established as the main commercial hub for domestic goods (personal goods, furniture, household appliances, computers, drugstore items, hardware, etc.). By 2015, there were nearly 3300 wholesale and semi-wholesale traders at its huge market, called the Dubai souk.

Organised into large specialised sectors, the El Eulma market is directly connected to marketplaces in China (Yiwu, Guangzhou, Shenzhen), the Middle Eastern and Europe. Welcoming thousands of buyers daily from throughout the country and, for several years now from Tunisia, this town ensures distribution through transport companies covering all of Algeria, as far as the great south (Belguidoum, Chouadra \& Alikhodja, 2017).

\section{Networks and Three Generations of Entrepreneurs}

This emergence of a transnational economy, and its speed and scale, raise questions about these new trader-entrepreneurs. Breaking with traditional trade circuits, their spirit of initiative is remarkable, especially since these entrepreneurs are often young. While some of them do come from merchant families, nothing predicted they would become the pioneers of these new routes.

Along with these young people who have a university or secondary education in a wide variety of disciplines, small traders are already integrated into the regional souk network, together with a few large established traders who seized the opportunity of this new trade. The convergence between these various experiences and related skills lead to this collective transformation.

Aïn Fakroun is an illustration of how quickly a trade route can be built thanks to flexible and efficient networks. At first, Aïn Fakroun's commercial activity was quite discreet. In the mid1980s, local young people took advantage of the region's extensive network of emigrants in France to start bag trading. Others initiated trade with Bir el-Ater, near the Tunisian border, which at that time was a hub for cross-border trade. The goods were sold on the local markets of the region as far as Constantine. Starting in 1992, Aïn Fakroun changed scale. Local traders set up their own networks in Libya and Egypt. The goods were brought by semi-trailer trucks, stored in Aïn Fakroun and resold in the urban markets of the region. In 1997, the first imports from Dubai arrived and local traders began to specialise in importing cheap clothing. By the early 2000s, the goods were brought directly from China. Flows from Yiwu, Guangzhou, and Shishi (in Fujian) were becoming more numerous - traders had followed the route back to its source.

Starting one's first trade business usually drew on family solidarity (father, brothers and uncles), or sometimes that of friends, who provided financial assistance and the information essential for this kind of work. Following the first major successes, other imitators arrived, encouraged by the availability of the market. They made it possible to organise networks that were both flexible and hierarchical, based on relationships of trust. 


\section{Pioneers on Transnational Routes}

The organisation of this kind of trade requires support in the countries where purchases are made. El Eulma's prosperity, for example, was due to the fact that the first traders to settle in Dubai were primarily from the same town. These pioneers also continued to move toward China and set up the first offices in Yiwu and Guangzhou.

In the mid-1990s, most Algerian importers still went to Istanbul, even though Dubai was an increasingly popular destination because it was considered the source. The majority of goods destined for Algeria arrived in Tunisia, Libya, or Egypt because there was only one direct container shipping line between Dubai and Algiers. This was the golden age of Dubai for these pioneers. Three agencies run by Algerians had a de facto monopoly in organising transactions with importers and wholesalers who then sold imported goods throughout Algeria.

The import business proved to be sufficiently lucrative that it quickly had emulators among wholesalers and then among their own customers in the early 2000s. The job of importer became commonplace, with multiple consequences. When small importers believed they were at the source in Dubai, those already in place used Dubai as a base for prospecting Asian supply centres in order to precede the small traders and offer them their services. From Dubai, these pioneers had already traveled regularly to Hong Kong, attended the annual Canton fair, and then the wholesale markets of Yiwu. In each of these cities, they opened their own offices between 2001 and 2005 in order to supply an increasing number of customers, mainly from eastern Algeria.

Algerian traders discovered Yiwu in the late 1990s. Pioneering traders from El Eulma and Bir El-Ater opened their trading offices there. The job of trading consists of supporting the importer when dealing with suppliers, acting as a translator, participating in negotiations, handling customs documents, checking the conformity of the goods and containerisation, organizing maritime transport, and serving as a guarantor to suppliers for payment delays.

In less than ten years, these pioneers consolidated their position as intermediaries in all import services along an axis stretching from El Eulma to Yiwu, passing through Dubai and Guangzhou. However, the competition was fierce and required the main players in the market to constantly update their offer. They needed to provide new products, enter new markets, and maintain their reputation and margins because they were quickly followed by others. Dubai and Yiwu were becoming starting points from which pioneers prospected for new buyers in east and central Africa: fewer demanding markets with less competition among importers.

Following the pioneers, other Eulmis, as well as young people from other towns in the east (Sétif, Bordj Bou Arredj, Constantine) and from Kabyle imitated them. A few hundred work as freight forwarders in Yiwu, Guangzhou, and Shenzhen. After the Egyptians, Syrians, Lebanese, and Turks, Algerians are the largest foreign community living in Yiwu, estimated 
in 2012 at 500 members. On the whole of China, Algerians are between two to three miles. Two types of actors make up this permanent community: big traders and a myriad of new entrants trying to make a name for themselves. About fifty big trading offices have hung out their shingle. They handle major export business to Algeria and are in contact with a large number of customers. They employ a local workforce (Hui and Uighur translators) as well as young people from Algeria (relatives and friends). Over the past two or three years, a new generation of small traders has been getting involved, who, while competing with the big offices, have taken advantage of the large amount of trade flows with Algeria to try to squeeze in. Coming directly from Algeria, they are sons or brothers of import traders or have learned the trade from a relative already settled in Guangzhou. Their setting up a business is part of a strategy to enable the family business to have a permanent base in China. Until they have a regular customer base, they operate without officially declaring their business, and thus partner with Chinese freight forwarders or work with larger Algerian traders. A few dozen undeclared traders work in this way. Unlike their predecessors who learned Chinese on the job, these new arrivals take language courses (a 6-month course in private schools for 8000 CNY). As a sign of their desire to settle in Yiwu long-term, marriages with Chinese women are contracted allowing for better social integration and undoubtedly better anchoring in a society where they have no or few cultural references, unlike France, a traditional country of Algerian emigration. This permanent presence of numerous and available freight forwarders makes it easier for importers to travel back and forth and guarantees faster delivery of orders that can also be placed by telephone. The job of trader also includes that of financial facilitator.

\section{Conclusion: Toward a New Era of Transnational Commerce}

The future of this economy is still problematic. Part of this market accumulation is expected to be invested in other sectors, such as industry and real estate. In general, trade routes and networks are constantly being restructured, marking their high instability. The ambiguities of Algeria's international trade policy and the government's repeated desire to tighten import conditions create permanent uncertainties for those working in international trade. To this, we must add the constant rise in currency prices (dollar, euro, and revaluation of the Yuan RMB) against an increasingly devalued dinar.

Competition among trade offices, their need to keep their customers, the opening of Chinese offices sending their own agents to Algeria, prospecting wholesalers by offering attractive credit rates, and China's visa limitations since 2016 are other elements to be considered.

However, over the past two years, there has been a trend towards reorganising trade circuits and a degree of professionalisation of transnational trade. The consolidation of regional redistribution marketplaces such as the dynamic El Eulma, has occurred alongside the professionalisation of the job of importer. The golden age of discovery in the late 2000s was followed by a period of restructuring driven by large Algerian importers and large offices in China, Yiwu, and Guangzhou. Transnational trade is entering a new era. 
ReferencesAddi, L., 1990, 'Forme néo-patrimoniale de l'Etat et secteur public en Algérie', in L.Addi, Lahouari, H. El Malki, JC. Santucci (eds.), Etat et développement dans le monde arabe, pp.17-34, Editions du CNRS, Paris.

Belguidoum, S., 2011, 'Le dynamisme des nouvelles places marchandes de l'Est algérien : reconfiguration urbaine et nouvelles donnes sociales', paper presented at the seminar Entre le licite et l'illicite: migrations, travail, marchés, 13 - 17th September 2011, Cerisy, France. from $\leq$ halshs-00936444>

Belguidoum S. \& Pliez O., 2015- 1, ' Made in China. Commerce transnational et espaces urbains autour de la Méditerranée', Les Cahiers d'EMAM, 26, pp.7-16 [Online] URL : http://emam.revues.org/909

Belguidoum S. \& Pliez O., 2015- 2, 'Yiwu: The Creation of a Global Market Town in China', Articulo - Journal of Urban Research [Online], 12, URL: http://articulo.revues.org/2863

Belguidoum S., Chouadra S. \& Alikhodja N., 2017, ' El Eulma (Algérie), anatomie d'une place emblématique du commerce transnational', Les Carnets de l'IREMAM, [Online] https://iremam.hypotheses.org/6456

Centre National du Registre du Commerce (CNRC), 2011, Les créations d'entreprises en Algérie, Statistiques 2010, Alger.

Eisenstadt, SN., 1973, Traditional Patrimonialism and Modern Neo Patrimonialism, London, Sage Publications Ltd.

Hachemaoui M., 2012, 'Institutions autoritaires et corruption politique. L'Algérie et le Maroc en perspective comparée', Revue internationale de politique comparée, 2012/2 (Vol. 19), pp. 141-164, Paris.

Médard JF., 1991, 'L'État néo-patrimonial en Afrique noire', in J.-F. Médard (eds.), États d'Afrique Noire : Formations, mécanismes et crises, p.323, Karthala, Paris.

Office National des Statistiques (ONS), 2012, Premier recensement économique-- 2011 Résultats définitifs de la première phase, Collections Statistiques 172/2012, Série E : Statistiques Economiques 69 - Alger

Péraldi M., 2001, Cabas et Containers, Activités marchandes informelles et réseaux migrants transfrontaliers, Paris, Aix-en-Provence, Maisonneuve \& Larose et MMSH

Péraldi M., 2007, ' Les aventuriers du nouveau capitalisme marchand ', In F. Adelhad et JF Bayart, Voyages du développement, pp.73-113, Editions Kartala - Ceri, Paris

Portes, A., 1999, 'Globalization from Below :The Rise of Transnational Communities', Actes de la recherche en sciences sociales, Volume 129 - 1 pp. 15-25, Paris, Le Seuil.

Tarrius A., 2002, La mondialisation par le bas: Les nouveaux nomades de l'économie souterraine, Balland, Paris. 
' This census, the first of its kind done in Algeria by the ONS, covered the entire country and counted all the companies conducting business in a fixed place during the reference period from 8 May - 8 August 2011. 